\title{
Radiographic Image Correlates with Tumor Pathology Finding
}

National Cancer Institute

\section{Source}

National Cancer Institute. Radiographic Image Correlates with Tumor Pathology Finding. NCI Thesaurus. Code C137939.

An indication that the results from radiographic and pathological testing correlate. 